\title{
PHENOTYPIC AND GENOTYPIC CHARACTERISTICS OF ENTEROCIN PRODUCING ENTEROCOCCI AGAINST PATHOGENIC BACTERIA
}

\author{
Sandra Mojsova ${ }^{1}$, Kiril Krstevski ${ }^{2}$, Igor Dzadzovski ${ }^{2}$, \\ Zagorka Popova ${ }^{2}$, Pavle Sekulovski ${ }^{1}$ \\ ${ }^{1}$ Food Institute, Faculty of Veterinary Medicine-Skopje, \\ Ss. Cyril and Methodius University in Skopje, Republic of Macedonia \\ ${ }^{2}$ Veterinary Institute, Faculty of Veterinary Medicine-Skopje, \\ Ss. Cyril and Methodius University in Skopje, Republic of Macedonia
}

Received 15 June 2015; Received in revised form 28 July 2015; Accepted 7 August 2015

\begin{abstract}
The study investigated the antimicrobial activity of 13 enterococcal strains (E. faecalis -8, E. faecium-2, E. hirae-2, E. spp.-1) isolated from our traditional cheeses against pathogen microorganisms. Also, it includes the detection of the following enterocin structural genes: enterocin A, enterocin B, enterocin P, enterocin L50A/B, bacteriocin 31, enterocin AS48, enterocin Q, enterocin EJ97 and cytolysin by using PCR method. All isolates inhibited growth of L. monocytogenes and L.innocua. One isolate had a broader antimicrobial activity. None of the isolates showed inhibitory activity against $S$. enteritidis, E. coli and $Y$. enterocolitica. The genes enterocin P, cytolysin and enterocin A were the most frequently detected structural genes among the PCR positive strains. No amplification was obtained in two strains E. faecalis-25 and E. faecalis-86. Three different genes were identified in some strains. With the exclusion of strains possessing a virulence factor, such as cytolysin, producers of more than one enterocins could be of a great technological potential as protective cultures in the cheese industry.
\end{abstract}

Key words: traditional cheese, enterococci, enterocins, antimicrobial activity

\section{INTRODUCTION}

The presence of pathogens in the dairy industry posses a potential risk and a constant concern in the field of food safety for consumers, food business operators and government authorities. A number of food borne disease outbreaks have been associated with these products (1). Although most of these outbreaks were closely related with the consumption of dairy products made from raw milk, post-processing contamination must be taken into account as an important risk factor in the manufacture of such products (2).

Corresponding author: Mojsova Sandra, MSc, DVM

E-mail address: kostova.sandra@fvm.ukim.edu.mk

Present address: Food Institute, Faculty of Veterinary Medicine

Ss. Cyril and Methodius University in Skopje

Lazar Pop-Trajkov 5-7, 1000 Skopje,

Republic of Macedonia

Phone: +38923240 736

Copyright: (C) 2015 Mojsova S. This is an open-access article published under the terms of the Creative Commons Attribution License which permits unrestricted use, distribution, and reproduction in any medium, provided the original author and source are credited.

Competing Interests: The authors have declared that no competing

interests exist.

Available Online First: 13 August 2015

http://dx.doi.org/10.14432/j.macvetrev.2015.08.052
Enterococci as a part of lactic acid bacteria (LAB) present a complex, divergent and significant group of bacteria in terms of their interaction with food and humans. Enterococci are omnipresent bacteria and are dominant residents of the digestive tract of humans and animals but their presence it's not unusual in the surrounding environment like soil, surface waters, plants and vegetables. They can also be found in food, especially in cheese (3). They are found in a high percentage as a part of the dairy microflora. They are especially found in a high percentage in many artisanal made cheeses traditionally produced in the countries from the Mediterranean region, mostly from raw ewe's or goat's milk. There is a widely spread opinion that these types of bacteria initially became contaminants from animal organic waste, water or milking equipment and storage tanks, and consequently became an essential component of artisanal cultures (4). These types of bacteria have a fundamental role in the ripening process of traditionally made cheeses (5). As a contribution to their involvement in the unique and specific peculiar taste and flavor, the enterococci also have 
the ability to protect from various pathogens (6). Recently, the scientific community has increased its interest in enterocins, encouraged by the fact that they act against food-borne pathogens, mostly against L. monocytogenes, S.aureus, B. cereus and vegetative cells and spores of $C$. botulinum $(7,8)$.

Lactic acid bacteria for centuries have been used in food and feed conservation and their preservative effects are mainly due to the decreasing of $\mathrm{pH}$ values and the formation of organic acids, principally lactic acid $(9,10,11)$. Bacteriocins are ribosomally synthesized polypeptides that possess antimicrobial activity and are commonly $\mathrm{pH}$ and heat tolerant and are rapidly digested by proteases in the human digestive tract due to their proteinaceous nature (12). Bacteriocins can also inhibit adulteration of food by preventing the outgrowth of non-pathogen and pathogen bacteria. The bacteriocin or bacteriocinproducing LAB except cytolysin, can be used as safe alternatives to chemical preservatives in foods $(11,13)$, because they are harmless to eukaryotic cells.

Beside the clear evidence that bacteriocinogenic enterococci and their bacteriocins are well known in the literature, the exploration in this field is still an actual subject of the research, as the isolation and characterization of the enterocin producing enterococci from different geographical areas, which have tradition for making artisanal dairy products, could perhaps give new data about the diversity and ecology of Enterococcus strains and their enterocins.

The objectives of this study were to identify bacteriocinogenic enteroccoci isolated from Macedonian traditional cheeses, as well as to determine the existence of bacteriocin structural genes.

\section{MATERIAL AND METHODS}

\section{Bacterial strains}

A collection of 13 Enterococcus strains that were previously isolated from traditional white pickled (brined) cheese from different regions of Macedonia were tested for presence of bacteriocin structural genes. The enterococci were isolated on a selective agar (KAA, Oxoid, UK) and identified by polymerase chain reaction (PCR) amplification of a part of 16S rRNA gene (14). Species determination was performed using PCR protocol for speciesspecific enterococcal targets $(14,15)$. Additionally, isolates negative on species-specific PCR were further determined by BLAST analysis of the $16 \mathrm{~S}$ rRNA sequences, using available sequence data from GenBank.
The following cultures were tested for sensitivity to enterocins: L. monocytogenes (NCTC 11994), L. innocua (cheese isolate), S. aureus (cheese isolate), P. aeruginosa (NCTC 10662), B. cereus (NCTC 7464), S. enteritidis (meat isolate), E. coli (NCTC 9001) and Y. enterocolitica (ATCC 11303).

\section{Bacteriocin production assay}

For the detection of antimicrobial activity, $50 \mu \mathrm{l}$ of an overnight culture of the indicator strain was added to $5 \mathrm{ml}$ molten soft semisolid Plate count agar (PCA), mixed and poured onto a solid PCA agar plate. A single colony of each enterococcus to be tested for antimicrobial activity was transferred with a sterile loop. Agar plates were incubated for $24 \mathrm{~h}$ at $37^{\circ} \mathrm{C}$ in aerobic condition. The antimicrobial activity was visually detected by observing clear zones around the tested strain. To test the proteinaceous nature of the inhibitors, $10 \mu \mathrm{l}$ of trypsin solution was deposited on the side of each spot of bacterial growth. The absence of inhibition in the trypsin-spotted zone indicated protease sensitivity.

\section{Detection by PCR of enterocin structural genes}

All isolates have been tested for the presence of the following bacteriocin structural genes: enterocin $\mathrm{A}$ (entA), enterocin $\mathrm{B}$ (entB), enterocin $\mathrm{P}$ (entP), enterocin L50A/B (entL50A-entL50B), bacteriocin 31 (bac31), enterocin AS48 (entAS48), enterocin Q (entQ), enterocin EJ97 (E21) and cytolysin (cyl) using specific enterocin PCR primers (Table 1).

Primers have been used in combinations giving four different duplex and two single-plex PCR reactions, as described in Table 1 and Table 2. All PCR reactions were set in a final volume of $20 \mu$, consisting of $17 \mu \mathrm{l}$ PCR mixture and $3 \mu \mathrm{l}$ DNA template, using Taq PCR Mastermix Kit (Qiagen, USA). Positive controls were included in PCR assays for detection of EntA, EntB, EntP, E21, EntAS48 and cyl genes, whereas positive controls weren't available for EntQ, Ent1071, Bac31, EntL50. Control DNA was obtained from isolates (FIFL-20, FIFL-36, FIFL-29, FIVRE-19) belonging to the culture collection of the Food Institute in which the presence of above mentioned structural genes has been confirmed by PCR.

The thermal profiles used for the amplification were the following: initial denaturation at $94^{\circ} \mathrm{C}$ for 3 minutes followed by 40 cycles of denaturation at $94{ }^{\circ} \mathrm{C}$ for 40 seconds, annealing $\left(50^{\circ} \mathrm{C}\right.$ for ent $\mathrm{A}$ and ent $\mathrm{Q}$ and $56^{\circ} \mathrm{C}$ for entP, entB, ent50A/B, bac31, entAS-48, ent1071A/B, E21) for 40 seconds, and elongation at $72^{\circ} \mathrm{C}$ for 60 seconds. Final extension was at $72^{\circ} \mathrm{C}$ for 10 minutes. 
Table 1. Primers used for PCR detection of bacteriocin genes

\begin{tabular}{|c|c|c|c|c|c|}
\hline Target gene & Primer & Sequence (5'-3') & fragment (bp) & PCR & Reference \\
\hline Enterocin A & $\begin{array}{l}\text { Ent Af } \\
\text { Ent Ar }\end{array}$ & $\begin{array}{l}\text { AAA TAT TAT GGA AAT GGA GTG TAT } \\
\text { GCA CTT CCC TGG AAT TGC TC }\end{array}$ & 126 & 1 & (16) \\
\hline Enterocin B & $\begin{array}{l}\text { EntBf } \\
\text { EntBr }\end{array}$ & $\begin{array}{l}\text { GAA AAT GAT CAC AGA ATG CCT A } \\
\text { GTT GCA TTT AGA GTA TAC ATT TG }\end{array}$ & 162 & 4 & (16) \\
\hline Enterocin Q & $\begin{array}{l}\text { EntQf } \\
\text { EntQr }\end{array}$ & $\begin{array}{l}\text { ATG AAT TTT CTT CTT AAA AAT GGT ATC GCA } \\
\text { TTA ACA AGA AAT TTT TTC CCA TGG CAA }\end{array}$ & 105 & 1 & (17) \\
\hline Enterocin P & $\begin{array}{l}\text { EntPf } \\
\text { EntPr }\end{array}$ & $\begin{array}{l}\text { TAT GGT AAT GGT GTT TAT TGT AAT } \\
\text { ATG TCC CAT ACC TGC CAA AC }\end{array}$ & 120 & 2 & (16) \\
\hline Enterocin L50 A/B & $\begin{array}{l}\text { EntL50f } \\
\text { EntL50r }\end{array}$ & $\begin{array}{l}\text { TGG GAG CAA TCG CAA AAT TAG } \\
\text { ATT GCC CAT CCT TCT CCA AT }\end{array}$ & 98 & 3 & (17) \\
\hline Bacteriocin 31 & $\begin{array}{l}\text { Bac31f } \\
\text { Bac31r }\end{array}$ & $\begin{array}{l}\text { TAT TAC GGA AAT GGT TTA TAT TGT } \\
\text { TCT AGG AGC CCA AGG GCC }\end{array}$ & 123 & 3 & (16) \\
\hline Enterocin AS48 & $\begin{array}{l}\text { EntAS48f } \\
\text { EntAS48r }\end{array}$ & $\begin{array}{l}\text { GAG GAG TTT CAT GAT TTA AAG A } \\
\text { CAT ATT GTT AAA TTA CCA AGC AA }\end{array}$ & 340 & 4 & (16) \\
\hline Enterocin EJ97 & $\begin{array}{l}\text { E21f } \\
\text { E21r }\end{array}$ & $\begin{array}{l}\text { GCA GCT AAG CTA ACG ACT } \\
\text { AGGGGAATTTGAACAGA }\end{array}$ & 279 & 5 & (18) \\
\hline Cytolysin & $\begin{array}{l}\text { Cylf } \\
\text { Cylr }\end{array}$ & $\begin{array}{l}\text { ACT CGG GGA TTG ATA GGC } \\
\text { GCT GCT AAA GCT GCG CTT }\end{array}$ & 688 & 6 & (19) \\
\hline
\end{tabular}

The thermal profile for cytolysin was the following: initial denaturation at $95^{\circ} \mathrm{C}$ for 2 minutes followed by 40 cycles of denaturation at $95^{\circ} \mathrm{C}$ for 30 seconds, annealing at $56^{\circ} \mathrm{C}$ for 90 seconds, elongation $72{ }^{\circ} \mathrm{C}$ for 90 seconds and final extension was at $72^{\circ} \mathrm{C}$ for 10 minutes. The amplification products were analysed by electrophoresis in $2.5 \%$ agarose gel at $7 \mathrm{~V} / \mathrm{cm}$ for $1.5 \mathrm{~h}$ in Tris-acetate-EDTA buffer and revealed in ethidium bromide $(20 \mu \mathrm{g} / \mathrm{mL})$. The gel was photographed using UV light.

\section{RESULTS}

Bacteriocin-producer isolates were identified as E. faecalis $(\mathrm{n}=8)$, E. faecium $(\mathrm{n}=2)$ and E. hirae $(\mathrm{n}=2)$. Species determination for one of the isolates (E.spp.-90) was inconclusive: despite the positive identification using 16S rRNA PCR, BLAST analysis of the amplified part of 16s RNA sequence revealed $100 \%$ similarity with Lactococcus lactis subsp. lactis. This finding imposes the necessity for further and deeper analysis of this isolate.

The 13 isolates were screened for antibacterial activity, since they may produce enterocins that can control the growth of the tested indicator bacteria. All of the isolates showed the activity predominantly against L. monocytogenes (Fig. 1), mostly showing larger inhibition zone for $L$. monocytogenes than L. innocua.

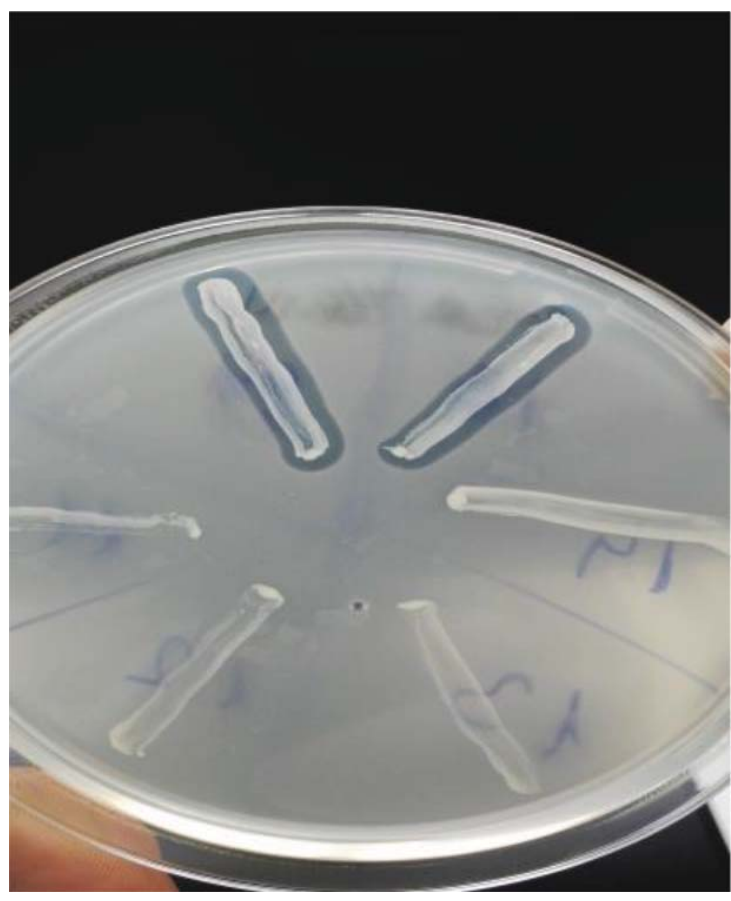

Figure 1. Inhibition areas against L. monocytogenes as a result of bacteriocin activity

Three of the isolates (E. faecalis-31, E.faecalis-32, E. hirae-36) were found to be inhibitory against $S$. aureus and $P$. aeruginosa, 


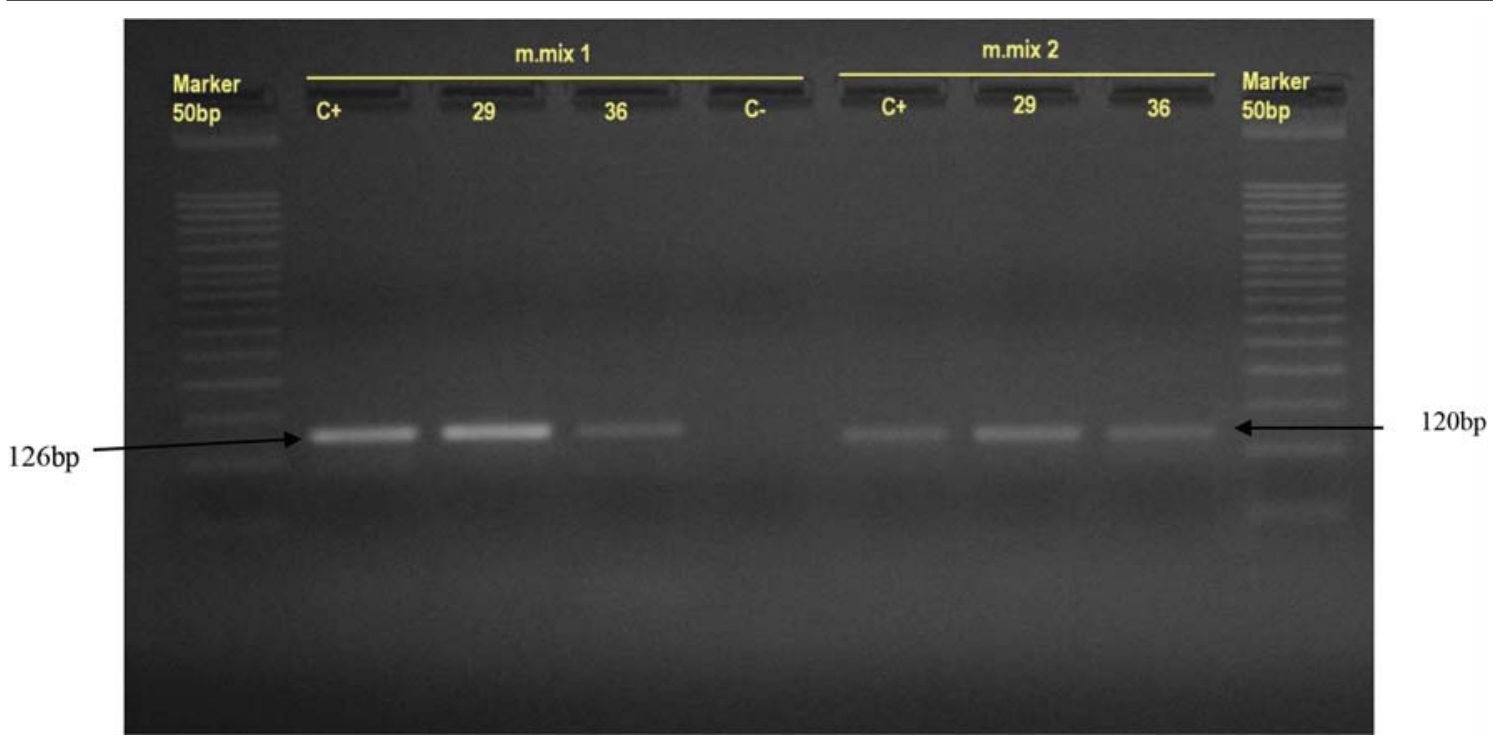

Figure 2. Agar gel visualisation of PCR products obtained with two duplex PCR reactions (PCR1 and PCR2). Lane Marker $50 \mathrm{bp}$ is $50 \mathrm{bp}$ ladder, lanes $\mathrm{C}+$ positive controls and lanes C- negative controls. Tested samples $(29,36)$ are in the lanes between positive and negative controls

but only two of them were found to be inhibitory against B. cereus (E. faecalis-31 and E. hirae-36). None of the isolates were found to be inhibitory against $S$. enteritidis, $Y$. enterocolitica and E. coli (Table 2). enterococci (Table 2). E. faecalis-4, E.faecium-15, E. faecium-29 and E. hirae-36 had three different structural enterocin genes. E. faecalis-31, E. faecalis-32, E. faecalis-51, E. faecalis-77 and E. spp. had only one structural enterocin gene.

Table 2. Enterocin genes and antimicrobial activity towards pathogens and their inhibition

\begin{tabular}{|c|c|c|c|c|c|c|c|c|c|c|}
\hline \multirow{2}{*}{ Isolate } & \multirow{2}{*}{ Source } & \multirow{2}{*}{$\begin{array}{c}\text { Enterocin } \\
\text { genes }\end{array}$} & \multicolumn{8}{|c|}{ Inhibition } \\
\hline & & & L. monocyt & L. innocua & S. aureus & B.cereus & P. aerugin. & Y. enterocol. & S. enteritidis & E. coli \\
\hline E. $f l-4$ & Cheese & $\mathrm{P}, \mathrm{B}, \mathrm{cyl}$ & + & + & - & - & - & - & - & - \\
\hline E. $f l-8$ & Cheese & P,cyl & + & + & - & - & - & - & - & - \\
\hline E. fm- 15 & Cheese & $\mathrm{A}, \mathrm{B}, \mathrm{P}$ & ++ & + & - & - & - & - & - & - \\
\hline E. $f l-25$ & Cheese & & ++ & + & - & - & - & - & - & - \\
\hline E. $f m-29$ & Cheese & $\mathrm{A}, \mathrm{B}, \mathrm{P}$ & +++ & + & - & - & - & - & - & - \\
\hline E. $f l-31$ & Cheese & Cyl & + & + & + & + & + & - & - & - \\
\hline E. $f l-32$ & Cheese & Cyl & + & + & + & - & + & - & - & - \\
\hline E. $h-36$ & Cheese & A, P, EJ97 & +++ & ++ & + & +++ & ++ & - & - & - \\
\hline E. $f l-51$ & Cheese & Cyl & + & + & - & - & - & - & - & - \\
\hline E. $h-52$ & Cheese & P, EJ97 & +++ & ++ & - & - & - & - & - & - \\
\hline E. $f l-77$ & Cheese & AS-48 & + & + & - & - & - & - & - & - \\
\hline E. $f l-86$ & Cheese & & + & + & - & - & - & - & - & - \\
\hline E.spp. 90 & Cheese & A & ++ & + & - & - & - & - & - & - \\
\hline
\end{tabular}

+ weak inhibition $(1-2 \mathrm{~mm}),++$ moderate inhibition $(3-4 \mathrm{~mm}),+++$ strong inhibition $(>4 \mathrm{~mm})$

The most frequent bacteriocin structural genes in this study were enterocin P, enterocin A and cytolysin, followed by enterocin B. Less frequent genes were EJ97 and AS-48. Enterocin Q, bacteriocin 31 and enterocin L50 were not found in the tested
Two of the isolates (E. faecalis -25 and $E$. faecalis-86), did not harbour any of the tested bacteriocins.

A gene for cytolysin was detected in 5 isolates of E. faecalis (E. faecalis-4, E. faecalis-8, E. faecalis-31, E. faecalis-32, E. faecalis -51). 
Phenotypic and genotypic characteristics of enterocin

\section{DISCUSSION}

Results from previous studies report identical findings that most enterocin producing enterococci show antilisterial activity, while a small part of them also show inhibitory activity against Staphylococcus aureus and Bacillus spp. (7, 20, 21). Gram-negative bacteria are mostly resistant to many enterocins and the absence of inhibitory activity against them is in agreement with the data that most of the bacteriocins produced by Enterococcus strains inhibit the growth of closely related bacteria and activity against Gram-negative bacteria is very rare $(22,23)$. Though, we found inhibitory activity against Pseudomonas aeruginosa. There are reports that certain lactic acid bacteria especially the class 2 bacteriocins - pediocins can inhibit a limited number of Gram-negative bacteria including Pseudomonas, Shigella sp. Salmonella sp. $(24,25)$.

According to our PCR results, different bacteriocin structural genes are spread among enterococcal strains. Enterocin A, B and P were the most prevalent among enterococci which is in accordance with the results obtained for enterococci isolated from different sources of food and feed, animal isolates, clinical and nonclinical human isolates (26), enterococci isolated from artisan food of animal origin (27) and Spanish goats milk cheeses (28). Earlier study showed that entAS-48 was widely distributed throughout E. faecalis (29), but there are also authors who did not detect the presence of enterocin AS-48 $(27,28)$. Contrary to our findings, no equivalence in results was found with this authors. Only in two isolates $(E$. faecalis-25 and E. faecalis-86), we could not detect presence of any of the tested enterocin genes. Still, these isolates showed inhibitory activity against. L. monocytogenes and L. innocua. This could be explained with the possible presence of other already known bacteriocins (non-tested in this study) or possible existence of novel bacteriocins. As previously published by Ozdemir et al., (30), bacteriocin production is correlated to the species. However, contrary to their findings we found in our study E. hirae and E. faecalis as bacteriocin producers.

Enterocin A and P belong to the family of pediocins and they are grouped as Class II 1 , which are effective mostly against listeria (31). Over the past ten years, class II bacteriocins produced by LAB have brought a significant attention to their potential application in food industry as natural preservatives and in the medical sector as antibiotic supplements or antiviral agents $(7,32)$. Enterocin
B belongs to the subgroup II 3, which are part of the non-pediocin type enterocin. Enterocin AS-48 belongs to the class of cyclic antibacterial peptides (33). It should be underlined that only one of our isolates (E. faecalis-77) showed exclusively the entAS-48 gene, which is opposite to the previous findings in the literature that this enterocin is widely distributed among E. faecalis and E. faecium (29).

The combination of three different enterocin genes was observed in four strains (E. faecalis-4, E. faecium-15, E. faecium-29, E. hirae-36). Combination of two enterocin genes was observed in two strains (E. faecalis-8, E. hirae-52). According to the reviewed literature enterocin $\mathrm{B}$ is found predominantly with enterocin $\mathrm{A}$, considering the fact that transport genes for enterocin B producers are not found $(26,34)$. In this study enterocin B was found with enterocin A, but it was also found in combination with enterocin P. It is considered by some authors that the reason for the high incidence of enterocin A, B and P genes in enterococcal bacteriocinogenic strains that are isolated from food is not only to antagonize bacteria but also to reinforce the competition of the selected strains against the competitors of the same species (35). Another combination of two genes is enterocin $\mathrm{P}$ and EJ97 and enterocin P, enterocin A and enterocin EJ97. These combinations, which were not found in the previous studies, were found in two of our isolates (E. hirae-36 and E. hirae-52).

Enterocin EJ97 belongs to enterocins synthesized without a leader peptide that is active against Gram-positive bacteria as well as enterococci, several species of Bacillus, Listeria and strains of S.aureus (36). Even though both strains (E. hirae -36 and $E$. hirae-52) posses the same structural gene EJ97, E. hirae-36 had a larger zone of inhibition. This could be explained by two possible hypotheses: the antimicrobial activity was reinforced by the presence of enterocin $\mathrm{P}$ and enterocin A or eventual presence of "silent" gene(s) in E. hirae-52. Various authors report the presence of bacteriocin silent genes in enterococci $(26,37,38)$.

Cytolysin was found only in E. faecalis isolates, which is the species with the highest occurrence of virulence genes. According to our results, it can be concluded that there is no large zone of inhibition around the strain that harbour a gene for cytolysin. Cytolysin is the only two-peptide lantiobiotic isolated from genus Enterococcus with cytolitic activity. Cytolysin is not considered useful due to the fact that it's a virulence factor (39), so these strains are not safe for application. 


\section{CONCLUSION}

Results of this study showed that further analysis of certain strains as adjunct cultures for the process of fermentation of dairy products is needed. Also further studies should be conducted in order to identify new antimicrobial substances produced by the enterococcal strains.

Due to the fact that cytolysin's virulence factor is not considered useful, so these strains are not safe for application. The usefulness of the strains that are free of cytolysin genes should be investigated, because these strains could be candidates for safe and practical use. Having in mind the potential of the strains, the future challenge will be optimizing the conditions during the fermentation process, as well as the composition of the medium in order to achieve better production of bacteriocin substances.

As a conclusion, our investigation gives a clear evidence of bacteriocin producing enterococci in traditional artisanal-produced cheese. The main bacteriocinogenic species was E. faecalis. Enterocin structural genes can be found in many different combinations, some of them reported for the first time in this study.

\section{REFERENCES}

1. Mead, P.S., Slutsker, L., Dietz, V., Mccaig, L.F.; Bresee, J.S.; Shapiro, C.; Griffin, P.M.; Tauxe, R.V. (1999). Food-related illness and death in the United States. Emerg. Infect. Dis. 5, 607-625.

http://dx.doi.org/10.3201/eid0505.990502

PMid:10511517 PMCid:PMC2627714

2. De Buyser, M.L., Dufour, B., Marie, M., Lafarge, V. (2001). Implication of milk and milk products in foodborne diseases in France and in different industrialized countries. Int. J. Food. Microbiol. 67, 1-17.

http://dx.doi.org/10.1016/S0168-1605(01)00443-3

3. Giraffa, G. (2002). Enterococci from foods FEMS Microbiology Reviews 26 pp. 163-171.

http://dx.doi.org/10.1111/j.1574-6976.2002.tb00608.x PMid:12069881

4. Folquie-Moreno, M. R., Sarantinoupulos, P., Tsakalidou, E., De Vuyst, L. (2006). The role and application of enterococci in food and health. Int. J. Food. Microbiol. 106, 1-24.

http://dx.doi.org/10.1016/j.ijfoodmicro.2005.06.026 PMid:16216368

5. Manolopoulou, E., Sarantinopoulos, P., Zoidou, E., Aktypis, A., Moschopoulou, E., Kandarakis, IG. (2003). Evolution of microbial populations during traditional Feta cheese manufacture and ripening. Int J Food Microbiol. 82(2):153-161. http://dx.doi.org/10.1016/S0168-1605(02)00258-1
6. De Vuyst, L.,. Vandamme E. J. (1994). Antimicrobial potential of lactic acid bacteria, p. 91-142. InL. de Vuyst and E. J. Vandamme (ed.), Bacteriocins of lactic acid bacteria: microbiology, genetics and applications. Blackie Academic \& Professional, London, United Kingdom.

7. Cleveland, J., Montville, T.J., Nes, I.F., Chikindas, M.L. (2001). Bacteriocins: safe natural antimicrobials for food preservation. Int. J. Food. Microbiol. 71,1-20. http://dx.doi.org/10.1016/S0168-1605(01)00560-8

8. Deegan, I. H., Cotter, P. D., Hill, C., Ross, P. (2006). Bacteriocins: biological tools for bio-preservation and shelf-life extension. Int Dairy J. 16, 1058-1071. http://dx.doi.org/10.1016/j.idairyj.2005.10.026

9. O’Sullivan, L., Ross, R.P., Hill, C. (2002). Potential of bacteriocin producing lactic acid bacteria for improvements in food safety and quality. Biochimie 84, 593-604. http://dx.doi.org/10.1016/S0300-9084(02)01457-8

10. Klaenhammer, T. R., Barrangou, R., Buck, B. L., Azcarate-Peril, M. A., Altermann, E. (2005). Genomic features of lactic acid bacteria effecting bioprocessing and health. FEMS Microbiol Rev. 29, 393-409.

http://dx.doi.org/10.1016/j.fmrre.2005.04.007 PMid:15964092

11. Casaus, P., Nilsen, T., Cintas, LM., Nes, IF., Hernández, PE., Holo, H. (1997). Enterocin B, a new bacteriocin from Enterococcus faecium T136 which can act synergistically with enterocin A. Microbiology 143(Pt 7):2287-2294.

http://dx.doi.org/10.1099/00221287-143-7-2287 PMid:9245817

12. Galvez, A., Abriouel, H.; Lopez, R.L.,Ben Omar, N. (2007). Bacteriocin-based strategies for food biopreservation. Int. J. Food. Microbiol. 120, 51-70.

http://dx.doi.org/10.1016/j.ijfoodmicro.2007.06.001 PMid:17614151

13. Bennik, M. et al. (1998). A novel bacteriocin with a YGNGV motif from vegetable-associated Enterococcus mundtii: full characterization and interaction with target organisms. Biochim. Biophys. Acta, 1373, 47-58.

http://dx.doi.org/10.1016/S0005-2736(98)00086-8

14. Dutka-Malen S, Evers S, Courvalin P. (1995). Detection of glycopeptide resistance genotypes and identification to the species level of clinically relevant enterococci by PCR. J Clin Microbiol., 33(1): 24-27.

15. Jackson, C.R., Fedorka-Cray, P.J., Barrett, J.B. (2004). Use of a genus- and species-specific multiplex PCR for identification of enterococci. J Clin Microbiol. 42, 3558-3565.

http://dx.doi.org/10.1128/JCM.42.8.3558-3565.2004 PMid:15297497 PMCid:PMC497640 
Phenotypic and genotypic characteristics of enterocin

16. Yousuf NMK, Dawyndt P, Abriouel H (2005). Molecular Characterization, technological properties and safety aspects of enteroccocci from Husuwa, an African fermented sorghum product. J Appl. Microbiol. 98, 216-228.

http://dx.doi.org/10.1111/j.1365-2672.2004.02450.x PMid:15610435

17. Ben Belgacem Z, Abriouel H, Ben Omar (2010). Antimicrobial activity, safety aspects and some technological properties of bacteriocinogenic Enterococcus faecium from artisanal Tunisian meat. Food Control 21, 462-470. http://dx.doi.org/10.1016/j.foodcont.2009.07.007

18. Sanchez-Hidalgo, M., Maqueda, M., Galvez, A., Valdivia, E. and Martinez-Bueno, M. (2003). The genes coding for enterocin EJ97 production by Enterococcus faecalis EJ97 are located on a conjugative plasmid. Appl Environ Microbiol. 62, 1633-1641. http://dx.doi.org/10.1128/AEM.69.3.1633-1641.2003 PMCid:PMC150074

19. Vankerckhoven, V., Van Autgaerden, T., Vael, C., Lammens, C., Chapelle, S., Rossi, R., Jabes, D., Goossens, H. (2004). Development of a multiplex PCR for the detection of asa1, gelE, cylA, esp and hyl genes in enterococci and survey for virulence determinants among European hospital isolates of Enterococcus faecium. J Clin Microbiol. 42, 4473-4479.

http://dx.doi.org/10.1128/JCM.42.10.4473-4479.2004 PMid:15472296 PMCid:PMC522368

20. Franz, C., Van Belkum, MJ., Holzapfel, WH., Abriouel, H., Gálvez, A. (2007). Diversity of enterococcal bacteriocins and their grouping into a new classification scheme. FEMS Microbiol Rev. 31: 293-310.

http://dx.doi.org/10.1111/j.1574-6976.2007.00064.x PMid:17298586

21. Giraffa, G. (1995). Enterococcal bacteriocins: their potential as anti-Listeria factors in dairy technology. Food Microbiol 12, 291-299. http://dx.doi.org/10.1016/S0740-0020(95)80109-X

22. Gong H. S., Meng X.C., Wang H. (2010). Plantaricin MG active against Gram negative bacteria produced by Lactobacillus plantarum KLDS1 isolated from "Jiaoke" a traditional fermented cream from China. Food Control, 21, 89-96. http://dx.doi.org/10.1016/j.foodcont.2009.04.005

23. Todorov., S. D., Dicks, L.M.T, (2005a). Lactobacillus plantarum isolated from molasses produces bacteriocins active against Gram-negative bacteria. Enzyme and Microbial Technology, 36. 318-326. http://dx.doi.org/10.1016/j.enzmictec.2004.09.009
24. Laukova A., Czikkova S., Vasilkova Z., Juris P., Marekova M (1998). Occurrence of bacteriocin production among environmental enterococci. Letters in Applied microbiology 27, 178-182.

http://dx.doi.org/10.1046/j.1472-765X.1998.00404.x PMid:9750323

25. Kwon DY, Koo M S, Ryoo CR, Kang CH, Min KH, Kim WJ (2002). Bacteriocin produced by Pediococcus sp. in kimchi and its characteristics. J. Microbiol. Biotechnol. 12, 96-105.

26. De Vuyst L., Foulquie Moreno M.R., Revets H. (2003). Screening for enterocins and detection of hemolysin and vancomycin resistance in enterococci of different originsInt. J. Food Microbiol., 84, 299-318. http://dx.doi.org/10.1016/S0168-1605(02)00425-7

27. Valenzuela AS, Ben-Omar N, Abriouel H, Lopez RL, Veljovic K, Canamero MM, Topisirovic MKL, Galvez A. (2009). Virulence factors, antibiotic resistance, and bacteriocins in enterococci from artisan foods of animal origin. Food Control. 20, 381-385. http://dx.doi.org/10.1016/j.foodcont.2008.06.004

28. Martin-Platero, A. M., Valdivia E, Maqueda M, Martinez-Bueno M. (2009) . Characterization and safety evaluation of Enterococci isolated from Spanish goats' milk cheeses. Int J of Food Microbiol, 132: 24-32.

http://dx.doi.org/10.1016/j.ijfoodmicro.2009.03.010 PMid:19375810

29. Joosten H. M., Rodriguez E, Nunez M (1997). PCR detection of sequences similar to the AS-48 structural gene in bacteriocin-producing enterococci. Lett Appl Microbiol. 24, 40-42.

http://dx.doi.org/10.1046/j.1472-765X.1997.00349.x PMid:9024003

30. Ozdemir, G,B., Oryasin, E., Biyuik, H. H., Ozteber, M., Bozdogan, B. (2011). Phenotypic and genotypic characterisation of bacteriocins in enterococcal isolates of different sources. Indian Journal of Microbiology. 51 (2): pp 182-187.

31. Eijsink VG, Skeie M, Middelhoven PH, Brurberg MB, Nes IF. (1998). Comparative Studies of Class IIa Bacteriocins of Lactic Acid Bacteria. Appl Environ Microbiol.; 64 (9): 3275-3281.

PMid:9726871 PMCid:PMC106721

32. Wachsman, M. B., Castilla, V., de Ruiz Holgado, A. P., de Torres, R. A., Sesma, F., Coto, C. E. (2003). Enterocin CRL35 inhibits late stages of HSV-1 and HSV-2 replication in vitro. Antiviral Res 58, $17-24$. http://dx.doi.org/10.1016/S0166-3542(02)00099-2

33. Nes, I.F., Diep, D.B., Havarstein, L.S., Brurberg, M.B., Eijsink, V., Holo, H., (1996). Biosynthesis of bacteriocins in lactic acid bacteria. Antonie van Leeuwenhoek 70, 113-128. http://dx.doi.org/10.1007/BF00395929 PMid:8879403 
34. Franz, C.M.A.P., Holzaphel, W.H. Stiles, M.E. (1999). Enterococci at the crossroads of food safety? Int. J. Food. Microbiol. 47, 1-24.

http://dx.doi.org/10.1016/S0168-1605(99)00007-0

35. Ben Omar, N., Castro, A., Lucas, R., Abriouel, H., Yousif, N.M.K., Franz, C.M.A.P., Holzapfel, W.H., Pérez-Pulido, R. et al. (2004). Functional and safety aspects of Enterococci isolated from different Spanish foods. Syst Appl Microbiol 27, 118-130. http://dx.doi.org/10.1078/0723-2020-00248 PMid:15053328

36. Gálvez, A., Valdivia Hikmate Abriouel, E., Mendez, E.C., Martínez-Bueno, M, Maqueda, M. (1998). Isolation and characterization of enterocin EJ97, a bacteriocin produced by Enterococcus faecalis EJ97Archives of Microbiology ; 171(1): 59-65.

37. Eaton, T.J, Gasson, M.J. (2001). Molecular screening of Enterococcus virulence determinants and potential for genetic exchange between food and medical isolates Appl. Environ. Microbiol., 67, 1628-1635. http://dx.doi.org/10.1128/AEM.67.4.1628-1635.2001 PMid:11282615 PMCid:PMC92779
38. Semedo T. S, Martins M. A., Lopes M. F. S., Figueiredo Marques J. J., Tenreiro R., Barreto Crespo M. T (2003). Comparative study using type strains and clinical and food isolates to examine hemolytic activity and occurrence of the cyl operon in enterococci J. Clin. Microbiol., 41, 2569-2576. http://dx.doi.org/10.1128/jcm.41.6.2569-2576.2003

39. Pangallo, D, Harichova, J, Karelova, E, Drahovska, H, Chovanova, K, Feriane, P, Turna, J, Timko, J. (2004). Molecular investigation of enterococci isolated from different environmental sources. Biologia $59,829-837$.

Please cite this article as: Mojsova S., Krstevski K., Dzadzovski I., Popova Z., Sekulovski P. Phenotypic and genotypic characteristics of enterocin producing enterococci against pathogenic bacteria. Mac Vet Rev 2015; 38 (2): 209-216. http://dx.doi.org/10.14432/j.macvetrev.2015.08.052 